\title{
ВІДТВОРНА ЗДАТНІСТЬ КОБИЛ РИСИСТИХ ПОРІД РІЗНОГО КЛАСУ ЖВАВОСТІ
}

\author{
Супрун Ірина Олександрівна \\ кандидат сільськогосподарських наук, доцент \\ Національний університет біоресурсів і природокористування України \\ ORCID: 0000-0001-8105-1923 \\ E-mail: isuprun@nubip.edu.ua
}

Враховуючи скорочення чисельності поголів'я коней рисистих порід, зниження рівня їх відтворення та тенденцію до ірраціональності структури поголів'я в кінних заводах метою даного дослідження було висвітлення сучасного стану рисистого конярства в Україні разом із вивченням відповіді організму кобил рисистих порід стосовно відтворної здатності на інтенсивність іподромних випробувань та тривалість іподромної експлуатації. Показано, що племінні коні рисистих порід (орловської, російської, фрранцузької) на початок 2020 року становили $26 \%$ від усієї чисельності племінних коней в Україні. За останні п'ятнадиять років поголів'я коней орловської та російської рисистих порід скоротилось на 60 - $81 \%$. У вітчизняному племінному конярстві в орловській породі спостерігається нераціональна структура поголів'я оскільки частка маточного складу на рівні $36 \%$ є недостатньою для повноцінного відтворення поголів'я. Вивчено відтворні якості кобил орловської та російської рисистих порід, залежність їх відтворних функцій від інтенсивності іподромних випробувань. Встановлено, що висока результативність виступів кобил орловської та російської рисистої породи в призах негативно впливає на їх відтворну здатність. Показано достовірні відмінності за рівнем прохолостів у кобил орловської та російської рисистої порід найвищого класу жвавості і груп з нижчими результатами.

Ключові слова: рисисті породи коней, кобила, жвавість, іподромні випробування, інтенсивність тренінгу, відтворна здатність, вихід лошат

DOI: https://doi.org/10.32845/bsnau.Ivst.2021.4.7

Не зважаючи на те, що міжнародні і національні аграрні програми ставлять пріоритетним завданням збереження генетичних ресурсів тваринництва, на сьогодні кінні заводи в Україні збиткові і не мають коштів для розширеного відтворення. Тому поголів'я цінних порід коней, навпаки скорочується, а їх генофонд збіднюється. Поруч із скороченням поголів'я рисистих порід, пов'язаним з економічною кризою в більшості кінних заводів, рівень їх відтворення також знижується $[1,3,19,20]$. У цілому в племінному конярстві спостерігається нераціональна структура поголів'я [3], а сучасні економічні умови України, в якості основного впливового чинника, зумовлюють незадовільну реалізацію генетичного потенціалу заводських порід[3, 19]. Основним напрямом селекційної роботи з кіньми рисистих порід $є$ селекція на підвищення жвавості та скороспілості $[2,4,18,22]$. Нажаль, коні рисистих порід як правило не відрізняються високою скороспілістю, їх ріст і розвиток закінчується до 3 5-річного віку. Тоді як іподромні випробування розпочинаються значно раніше (1,5 -2 роки) в умовах форсованого тренінгу, спрямованого на прояв жвавості саме в молодшому віці. Саме така особливість тренінгу і випробувань у коней обох статей викликає значне перенапруження усіх систем організму. Для кобил раннє використання, напружений тренінг, вплив стресових ситуацій під час іподромних випробувань $€$ особливо небезпечним і не завжди компенсаторним. Так у проведених ученими дослідженнях було встановлено, що система випробувань коней, яка практикується на іподромах, не завжди гарантує збереження нормальної відтворної функції кобил і приводить до різних форм експлуатаційного безпліддя в перші роки відтворної діяльності. Пояснюється це тим, що одночасне підвищення інтенсивності тренувань 3 мобілізацією рухової активності на фоні активованої функціональної системи відтворення створює передумови для конкуренції цих двох систем на рівні гормональної регуляції. В результаті у кобил можуть виникати різні патології відтворної системи, завдяки чому і знижуються показ-

ники відтворення у них [2, 17, 23], а відновлення репродуктивної системи відбувається лише через кілька років $[4,18$, 21].

Враховуючи скорочення чисельності поголів'я коней рисистих порід, зниження рівня їх відтворення та тенденцію до ірраціональності структури поголів'я в кінних заводах метою даного дослідження було висвітлення сучасного стану рисистого конярства в Україні разом із вивченням відповіді організму кобил рисистих порід стосовно відтворної здатності на інтенсивність іподромних випробувань та тривалість іподромної експлуатації.

Матеріали та методи досліджень. Для висвітлення сучасного стану рисистого конярства в Україні був використаний Державний реєстр суб'єктів племінної справи у тваринництві за 2005 - 2020 рр [5-16] та дані багаторічних досліджень галузі конярства України. Матеріалом для вивчення відтворної здатності кобил послужили картотеки племінних кобил орловської та російської рисистих порід та зведені бонітувальні відомості коней Дібрівського кінного заводу.

Результати дослідження. В умовах тривалої кризи за останні 15 років племінне конярство в Україні зазнало суттєвого скорочення чисельності поголів'я, звуження породної структури та зміни форми власності. Так, на початок 2020 року в Україні за даними Державного реєстру суб'єктів племінної справи у тваринництві існує 38 суб'єктів по племінній роботі: 15 кінних заводи, 23 племінних репродуктори [19]. Коні 3 рисистих порід (орловської, російської, французької) на початок 2020 року становили $26 \%$ від усієї чисельності племінних коней - 735 голів. Орловська рисиста порода коней $є$ третьою за чисельністю в Україні і найчисельнішою серед рисистих порід. Результат відтворного схрещування американських та орловських рисаків - російська рисиста порода, $є$ четвертою за представництвом серед усіх племінних коней [20].

За результатами досліджень можна стверджувати про значне скорочення поголів'я коней орловської та росій- 
ської рисистих порід за останні п'ятнадцять років. Станом на 01012021 року загальна чисельність коней орловської рисистої породи у 2 кінних заводах та 3 племінних репродукторах становить 509 голів, в тому числі 21 жеребців та 186 кобил, що на 14 \% менше порівняно з минулим (2020) ро- ком (рис.). Порівняно з 2015 роком чисельність коней даної породи скоротилась на 25,81 \%, а за останні 15 років поголів'я зменшилось аж на $60 \%$. Середній вихід лошат в орловській рисистій породі становить $86 \%$, що на $6 \%$ більше від минулорічного показника.

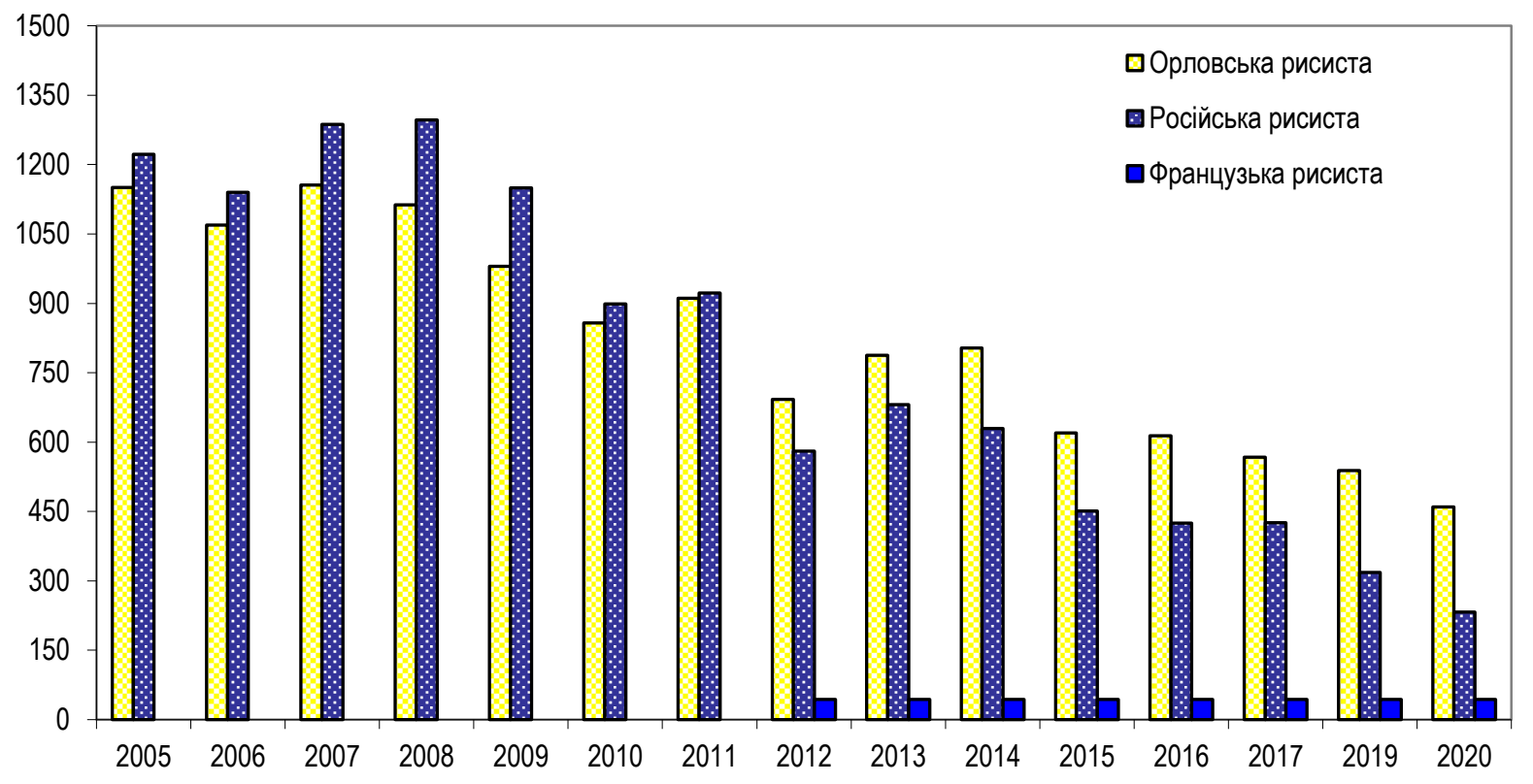

Рис. Динаміка чисельності коней рисистих порід в Україні за 2005-2020 рр

Станом на 1.01.2021 у 3 кінних заводах та 2 племінних репродукторах з розведення коней російської рисистої породи утримувалося 268 голови коней, в тому числі 12 жеребців-плідників і 124 племінних кобили. що на 27\% менше порівняно 3 початком минулого року та на 48,55\% менше порівняно з 2015. За останні п'ятнадцять років поголів'я коней російської рисистої породи зменшилось на $81 \%$.

В структурі поголів'я племінних коней орловської рисистої породи питома вага кобил за останні 5 років не перевищує $36,54 \%$, що $є$ недостатнім для повноцінного відтворення поголів'я (табл 1.). У російські рисистій породі частка кобил дещо вища порівняно з орловською. Згідно з нашими даними,, вона має тенденцію до зростання в останні роки і на початок 2021 року було зафіксовано обнадійливі 46,26\%.

Таблиця 1

Динаміка структури поголів'я племінних коней рисистих порід

\begin{tabular}{|c|c|c|c|c|c|c|c|c|c|}
\hline \multirow{4}{*}{ Рік } & \multicolumn{9}{|c|}{ Порода } \\
\hline & \multicolumn{3}{|c|}{ Орловська } & \multirow{2}{*}{\multicolumn{3}{|c|}{$\begin{array}{l}\text { Російська рисиста } \\
\text { Чисельність коней }\end{array}$}} & \multicolumn{3}{|c|}{ Французька рисиста } \\
\hline & & Чиселью & ь коней & & & & & Чисел & сть коней \\
\hline & Всього & Жеребці & Частка кобил,\% & Всього & Жеребці & Частка кобил,\% & Всього & Жеребці & Частка кобил,\% \\
\hline 2005 & 1151 & 43 & 30,40 & 1222 & 50 & 29,29 & - & - & - \\
\hline 2006 & 1069 & 45 & 36,20 & 1140 & 50 & 30,87 & - & - & - \\
\hline 2007 & 1156 & 62 & 34,51 & 1287 & 55 & 32,16 & - & - & - \\
\hline 2008 & 1113 & 58 & 33,96 & 1297 & 57 & 33,30 & - & - & - \\
\hline 2009 & 980 & 49 & 33,46 & 1150 & 58 & 36,26 & - & - & - \\
\hline 2010 & 858 & 48 & 35,66 & 899 & 40 & 34,81 & - & - & - \\
\hline 2011 & 911 & 54 & 32,93 & 922 & 38 & 32,97 & 43 & 3 & 34,88 \\
\hline 2012 & 692 & 42 & 38,15 & 580 & 32 & 38,79 & 43 & 3 & 34,88 \\
\hline 2013 & 788 & 49 & 36,67 & 681 & 35 & 36,56 & 43 & 3 & 34,88 \\
\hline 2014 & 803 & 47 & 35,99 & 629 & 39 & 36,24 & 43 & 3 & 34,88 \\
\hline 2015 & 620 & 32 & 35,32 & 451 & 23 & 39,68 & 43 & 3 & 34,88 \\
\hline 2016 & 614 & 28 & 35,34 & 425 & 20 & 39,76 & 43 & 3 & 34,88 \\
\hline 2017 & 567 & 21 & 36,15 & 426 & 20 & 38,49 & 43 & 3 & 34,88 \\
\hline 2018 & 538 & 21 & 33,64 & 426 & 20 & 38,49 & 43 & 3 & 34,88 \\
\hline 2019 & 538 & 22 & 33,64 & 318 & 15 & 44,02 & 43 & 3 & 34,88 \\
\hline 2020 & 534 & 22 & 34,08 & 344 & 14 & 45,15 & 43 & 3 & 34,88 \\
\hline 2021 & 509 & 21 & 36,54 & 268 & 12 & 46,26 & 43 & 3 & 34,88 \\
\hline
\end{tabular}

3 метою вивчення впливу інтенсивності іподромних випробувань на відтворну здатність кобил рисистих порід всі рисисті кобили маточного складу Дібрівського кінного заводу були умовно розподілені на три групи. До першої було 
включено тих, що мали жвавість вище 2 хвилин 10 секунд (високий клас жвавості). Друга група складалась з кобил із класом жвавості в межах 2 хвилини 10,1 секунди та 2 хвилини 15 секунд і тихіше (низький клас). До третьої групи були включені кобили маточного складу, що не випробовувались на іподромі.

Усіх кобил було оцінено за тривалістю перебування у маточному складі, за наявністю абортів і прохолостів, кількістю отриманих від них лошат, та їх життєздатністю. Результатом оцінки став підрахунок виходу лошат для кожної групи кобил за класом жвавості.

Оскільки в перших двох групах кобил, які випробовувались на іподромі, різниця за кількістю живих, слабких чи мертвих лошат недостовірна не можна стверджувати, що сам по собі клас жвавості впливає на життєздатність майбу- тнього приплоду. Кількість прохолостів та абортів у групі кобил високого класу жвавості достовірно вища, тому можна висловити припущення, що загалом фізичні навантаження та стреси від участі в змаганнях мали вплив на відтворні якості кобил орловської та російської рисистих порід.

Припущення про те, що висока результативність виступів кобил орловської рисистої породи в призах негативно впливає на їх відтворну здатність, доводить і встановлена нами достовірна відмінність (при $\mathrm{P}>0,95$ ) між рівнем прохолостів у кобил орловської рисистої породи групи найвищого класу жвавості і кобил групи з низьким результатом (табл. 2.). За іншими показниками відтворної здатності між кобилами, що увійшли до даних груп, достовірних відмінностей не виявлено.

Показники відтворення кобил орловської рисистої породи різних класів жвавості

\begin{tabular}{|c|c|c|c|c|c|c|c|c|c|}
\hline \multirow{3}{*}{ Клас } & \multirow{3}{*}{$\begin{array}{c}\text { Жвавість } \\
\text { (хв.С) }\end{array}$} & \multirow{3}{*}{ Поголів'я } & \multirow{3}{*}{$\mathrm{T}^{*}$, років } & \multicolumn{5}{|c|}{ Кількість, гол. } & \multirow{3}{*}{$\begin{array}{c}\text { Вихід лошат на } \\
100 \text { кобил, \% }\end{array}$} \\
\hline & & & & \multicolumn{3}{|c|}{ Народжених лошат } & \multirow{2}{*}{ абортів } & \multirow{2}{*}{ прохолостів } & \\
\hline & & & & живих & слабких & мертвих & & & \\
\hline $2.05,1-2.10$ & $2.08,5$ & 19 & 8,9 & 5,8 & 0,2 & - & 0,4 & 2,5 & 65,2 \\
\hline 2.10,1-2.15 і тихіше & $2.15,8$ & 104 & 8,0 & 5,7 & 0,2 & 0,1 & 0,2 & 1,8 & 71,3 \\
\hline Не випробувані & - & 4 & 5,2 & 3,5 & - & - & - & 1,7 & 67,3 \\
\hline
\end{tabular}

$T^{*}$ - термін перебування кобил в маточному складі

Щодо кобил російської рисистої породи даного заводу, окремо було виділено групу найбільш жвавих кобил класу жвавості 2 хвилини 5 секунд і жвавіше (табл. 3.). Саме в цій групі виявлено найбільшу кількість прохолостів у кобил та вищу, порівняно з іншими групами, смертність у новона- роджених. Тому у кобил російської рисистої породи різниця за рівнем прохолостів між групою кобил найвищого класу жвавості (2.05 і жвавіше) і кобилами менш престижних класів у них ще більше помітна.

Показники відтворення кобил російської рисистої породи різних класів жвавості

\begin{tabular}{|c|c|c|c|c|c|c|c|c|c|}
\hline \multirow{3}{*}{ Клас } & \multirow{3}{*}{$\begin{array}{c}\text { Жвавість } \\
\text { (хв.с) }\end{array}$} & \multirow{3}{*}{ Поголів'я } & \multirow{3}{*}{$\mathrm{T}^{*}$, років } & \multicolumn{5}{|c|}{ Кількість, гол. } & \multirow{3}{*}{$\begin{array}{c}\text { Вихід лошат на } \\
100 \text { кобил, \% }\end{array}$} \\
\hline & & & & \multicolumn{3}{|c|}{ народжених лошат } & \multirow{2}{*}{ абортів } & \multirow{2}{*}{ прохолостів } & \\
\hline & & & & живих & слабих & мертвих & & & \\
\hline 2.05 і жвавіше & $2.03,6$ & 29 & 9,6 & 5,5 & 0,13 & 0,24 & 0,3 & 3,43 & 53,7 \\
\hline $2.05,1-2.10$ & $2.09,6$ & 60 & 9,0 & 5,4 & 0,20 & 0,11 & 0,3 & 2,99 & 60,0 \\
\hline 2.10,1-2.15 і тихіше & $2.15,3$ & 41 & 9,0 & 6,4 & 0,10 & 0,17 & 0,4 & 1,93 & 71,1 \\
\hline Не випробувані & - & 3 & 6,0 & 4,3 & - & - & 0,3 & 1,40 & 71,7 \\
\hline
\end{tabular}

$T^{*}$ - термін перебування кобил в маточному складі

Так, різниця між найкращими за жвавістю кобилами і кобилами наступного по рангу класу складає 12,8\%; між найкращими за жвавістю і кобилами низького класу жвавості - різниця 43,79\%. Найвищою є міжгрупова диференціація у кобил найвищого класу жвавості та групою невипробуваних на іподромі кобил - 59\%.

Вихід лошат від кобил з найвищою жвавістю, а як результат - і вищою інтенсивністю участі у іподромних випробуваннях та змаганнях, теж достовірно нижчий. Так, порівняно 3 другою групою (високий клас жвавості) ця різниця складає 6,3\%, порівняно з третьою (низький клас жвавості) $17,4 \%$; порівняно з четвертою групою (не випробовувались) $-18 \%$.

Знижені показники плодючості кобил обох порід престижних класів жвавості (2 хв. 05 сек. і жвавіше, 2 хв. 05,1 сек. - 2 хв. 10 сек.) обумовлені тривалою та інтенсивною іподромною експлуатацією, яка сприяє більш повній реалізації їх генетичного потенціалу i, разом з тим, негативно впливає на відтворну здатність. Основний показник плодючості (вихід лошат) у кобил класу 2 хв. 05 сек. і жвавіше російської рисистої породи складає лише $53,7 \%$, а у кобил класу жвавості 2 хв. 05,1 сек. - 2 хв. 10 сек. - 60,80\%, що нижче за аналогічні показники кобил «тихіших» класів жвавості.

Потрібно також відмітити тенденцію до гіршого виходу лошат в російській рисистій породі порівняно з орловськими кобилами аналогічних класів жвавості. Так, різниця за виходом лошат на 100 кобил між групами високого класу жвавості складає 5,2\%. Достовірною є міжпорідна різниця за даним показником і в групах кобил орловської та російської рисистих порід, які ніколи не випробовувались на іподромі, $4,4 \%$.

Висновки. 1. Коні орловської, російської, фрранцузької рисистих порід на початок 2020 року становили $26 \%$ від усієї чисельності племінних коней. Орловська та російська рисиста порода займають третє і четверте місце за чисельністю племінних коней в Україні. За останні п'ятнадцять років поголів'я коней орловської та російської рисистих порід скоротилось на $60-81 \%$.

2. У вітчизняному племінному конярстві в орловській породі спостерігається нераціональна структура поголів'я оскільки частка маточного складу $36,54 \% \in$ недостатньою для повноцінного відтворення поголів'я.

3. Клас жвавості не чинить негативного впливу на 
плодючість кобил рисистих порід, але пов'язані з нею тривалість та інтенсивність іподромної експлуатації, негативно впливають на їх відтворну здатність та показники плодючосTi.

4. Кобили орловської рисистої породи, що показали помірну жвавість (2 хв. 10,1 сек. і тихіше) характеризуються вищою плодючістю, що обумовлено зниженою інтенсивністю експлуатації їх на іподромі. Вихід лошат у представниць даного класу жвавості складає 71,3\%, що значно перевищує показники кобил престижнішого класу жвавості - 2 хв. 05,1 сек. - 2 хв. 10 сек. (при $\mathrm{P}>0,95)$.

5. Кобили російської рисистої породи, що показали помірну жвавість (2 хв. 10,1 сек. і тихіше), характеризуються найвищою плодючістю, що обумовлено зниженою інтенсивністю експлуатації їх на іподромі. Вихід лошат у представ- ниць даного класу жвавості складає 71,1\%, що значно перевищує показники кобил найпрестижніших класів жвавості - 2 хв. 05 сек. і жвавіше, 2 хв. 05,1 сек. - 2 хв. 10 сек. (при Р>0,95). Підтвердженням цього $€$ найвищий вихід лошат у кобил, які взагалі не випробовувались на іподромі, - 71,7\%.

6. Висока результативність виступів кобил орловської та російської рисистої породи в призах негативно впливає на їх відтворну здатність. Встановлені достовірні відмінності (при Р>0,95) між рівнем прохолостів у кобил орловської та російської рисистої порід найвищого класу жвавості і груп 3 нижчими результатами. Найвищою є міжгрупова диференціація у кобил російської рисистої породи найвищого класу жвавості та групою невипробуваних на іподромі кобил $-59 \%$

\section{Список використаної літератури:}

1. Алексеев М.Ю. Леонова М.А. Воспроизводительная функция и стресс-реакция организма тренируемых кобыл. Резервы повышения эфффективности коневодства и коннозаводства: Сб. науч. трудов ВНИИК. 1987. С. 88 - 92.

2. Алексеев М.Ю., Леонова М.А., Матвеева Л. Воспроизводительная функция кобыл в период ипподромных испытаний. Коневодство и конный спорт. 1998, № 2. С. 32 - 38.

3. Вербицький П.І., Микитюк Д.М., Білоус О.В., Ткачова І.В., Костенко О.І., Генетичні ресурси коней в Україні. Науково-технічний бюлетень. 2008, № 98. С.3 - 11.

4. Гопка Б.М., Максименко JІ.В. Резвостной класс и особенности воспроизводства кобыл.: Науч. тр. УСХА. - Киев, 1976. Вып. 182. С.61-64.

5. Державний племінний реєстр 2005 рік. Державний науково-виробничий концерн «Селекція», 2006. Т. II. 310с.

6. Державний племінний реєстр 2006 рік. Державний науково-виробничий концерн «Селекція», 2007. Т. II. 310с.

7. Державний племінний реєстр 2007 рік. Державний науково-виробничий концерн «Селекція», 2008. Т. II. 310с.

8. Державний племінний реєстр 2008 рік. Київ: Державний науково-виробничий концерн «Селекція», 2009. Т. II. 310с.

9. Державний племінний реєстр за 2010 рік. Київ: Укрплемоб'єднання, 2011. Т. II. 332с.

10. Державний реєстр суб'єктів племінної справи у тваринництві за 2014 рік / за ред. С. В. Прийми. Київ, 2015. Т. II. 319 c. http://animalbreedingcenter.org.ua/images/files/deriplemreestr/deriplemreestr_tom2_2014.pdf

11. Державний реєстр суб'єктів племінної справи у тваринництві за 2015 рік / за ред. С. В. Прийми. Київ, 2016. Т. II. 319 c. http://animalbreedingcenter.org.ua/images/files/deriplemreestr/deriplemreestr tom2 2015.pdf

12. Державний реєстр суб'єктів племінної справи у тваринництві за 2016 рік / за ред. С. В. Прийми. Київ, 2017. Т. II. 307 c. http://animalbreedingcenter.org.ua/images/files/deriplemreestr/deriplemreestr tom2 2016.pdf

13. Державний реєстр суб'єктів племінної справи у тваринництві за 2017 рік /за ред. С. В. Прийми. Київ, 2018. Т. ІІ. 307 c. http://animalbreedingcenter.org.ua/images/files/deriplemreestr/deriplemreestr tom2 2017.pdf

14. Державний реєстр суб'єктів племінної справи у тваринництві за 2018 рік / за ред. С.В. Прийми. Київ, 2019. Т. II. 294 c. http://animalbreedingcenter.org.ua/images/files/deriplemreestr/deriplemreestr tom2_2018.pdf

15. Державний реєстр суб'єктів племінної справи у тваринництві за 2019 рік / за ред. С.В. Прийми. Київ, 2020. Т. II. 294 c. deriplemreestr tom2 2019.pdf (animalbreedingcenter.org.ua)

16. Державний реєстр суб'єктів племінної справи у тваринництві за 2020 рік / за ред. С.В. Прийми. Київ, 2021. Т. ІІ. 294 c. http://animalbreedingcenter.org.ua/images/files/deriplemreestr/deriplemreestr2_2020.pdf

17. Козлов С.А., Игнатов А.В. Влияние ипподромных испытаний на воспроизводительную способность кобыл орловской рысистой породы. Коневодство и конный спорт. 2012. №4. С. 10 - 14.

18. Игнатов А.В. Особенности воспроизводства лошадей орловской рысистой породы в условиях интенсивной селекции на резвость: автореф. дисс.... канд. с.-х. наук/M., 2009. 18c. https://www.dissercat.com/content/osobennostivosproizvodstva-loshadei-orlovskoi-rysistoi-porody-v-usloviyakh-intensivnoi-sele

19. Супрун І.О. Стан і перспективи застосування генетичних ресурсів конярства в Україні. Технологія виробництва і переробки продукції тваринництва, Біла Церква, 2020. № 2. C.66 - 75. DOI: 10.33245/2310-9289-2020-158-2-66-75

20. Супрун І.О. Генетичні ресурси рисистого конярства в Україні. Вісник Сумського Національного аграрного університету, Суми, 2020. Серія Тваринництво Випуск 3(42). C. 67 - 76. DOI: 10.32845/bsnau.lvst.2020.3.12

21. Фомина Е.Л., Мирошникова К.И., Валк И.А. Воспроизводительная функция орловских и русских кобыл в условиях Дубровского конного завода. Интенсификация селекции и технологии выращивания лошадей: Сб. науч. тр. ВНИИК. 1988. C. $190-201$.

22. Cotran E.G., Maccluer J.W., Weitkamp L.R., Pfenning D.W. Inbreeding and reproductive performance in standardbred horses. The Journal of Heredity. 1984. Vol. 75. № 3. P. 220 - 224.

23. Roche J.F., Kecnan L., Forde D. Some factors affecting fertility of the mare. Equine Practice. 1987. Vol. 9. № 1. P. 8 - 12.

References:

1. Alekseev, M.Yu., Leonova, M.A., 1987. Vosproyzvodytelnaia funktsyia y stress-reaktsyia orhanyzma trenyruemykh kobyl. 
[Reproductive function and stress response of the body of trained mares]. Rezervy povyshenyia effektyvnosty konevodstva $y$ konnozavodstva. 1987.pp. 88 - 92.

2. Alekseev, M.Yu., Leonova M.A, Matveeva L., 1998. Vosproyzvodytelnaia funktsyia kobyl v peryod yppodromnykh yspytanyi. [Reproductive function of mares during the hippodrome trials]. Konevodstvo y konnyi sport. No. 2. pp. 32 - 38.

3. Verbitsky, P.I, Mikityuk, D.M, Bilous, O.,V, Tkachova, I.V, Kostenko, O.I, 2008. Henetychni resursy konei v Ukraini. [Genetic resources of horses in Ukraine]. Naukovo-tekhnichnyi biuleten. 2008, No. 98. pp.3 - 11.

4. Gopka, B.M., Maksimenko, L.B., 1976. Rezvostnoi klass y osobennosty vosproyzvodstva kobyl [Abrasive class and reproductive characteristics of mares.]: Scientific works. Киев, 1976. Issue. 182. pp.61-64.

5. Pryjma, S. V. ed., 2016. Derzhavnyj reyestr subyektiv pleminnoyi spravy u tvarynnycztvi za 2015 rik [State register of subjects of breeding business in animal husbandry for 2015]. Kyiv. http://animalbreedingcenter.org.ua/images/files/derjplemreestr/derjplemreestr_tom2_2015.pdf

6. Pryjma, S. V. ed., 2017. Derzhavnyj reyestr subyektiv pleminnoyi spravy u tvarynnycztvi za 2016 rik [State register of subjects of breeding business in animal husbandry for 2016]. Kyiv. http://animalbreedingcenter.org.ua/images/files/deriplemreestr/deriplemreestr_tom2_2016.pdf

7. Pryjma, S. V. ed., 2018. Derzhavnyj reyestr subyektiv pleminnoyi spravy u tvarynnycztvi za 2017 rik [State register of subjects of breeding business in animal husbandry for 2017]. Kyiv. http://animalbreedingcenter.org.ua/images/files/derjplemreestr/derjplemreestr_tom2_2017.pdf

8. Pryjma, S. V. ed., 2019. Derzhavnyj reyestr subyektiv pleminnoyi spravy u tvarynnycztvi za 2018 rik [State register of subjects of breeding business in animal husbandry for 2018]. Kyiv. http://animalbreedingcenter.org.ua/images/files/deriplemreestr/deriplemreestr_tom2_2018.pdf

9. Pryjma, S. V. ed., 2020. Derzhavnyj reyestr subyektiv pleminnoyi spravy u tvarynnycztvi za 2019 rik [State register of subjects of breeding business in animal husbandry for 2019]. Kyiv. deriplemreestr tom2_2019.pdf (animalbreedingcenter.org.ua)

10. Pryjma, S. V. ed., 2021. Derzhavnyj reyestr subyektiv pleminnoyi spravy u tvarynnycztvi za 2020 rik [State register of subjects of breeding business in animal husbandry for 2020]. Kyiv http://animalbreedingcenter.org.ua/images/files/derjplemreestr/derjplemreestr2_2020.pdf Selekciya.

11. State Tribal Register 2005, 2006. Kyiv: Ministry of Agrarian Policy of Ukraine. State Scientific and Production Concern

12. State Tribal Register 2006, 2007. Kyiv: Ministry of Agrarian Policy of Ukraine. State Scientific and Production Concern Selekciya. Selekciya.

13. State Tribal Register 2007, 2008. Kyiv: Ministry of Agrarian Policy of Ukraine. State Scientific and Production Concern

14. State Tribal Register 2008, 2009. Kyiv: Ministry of Agrarian Policy of Ukraine. State Scientific and Production Concern Selekciya.

15. State Tribal Register 2009, 2010. Kyiv: Ministry of Agrarian Policy of Ukraine. Ukrplemobyednannya.

16. State Tribal Register 2010, 2011. Kyiv: Ministry of Agrarian Policy of Ukraine. Ukrplemobyednannya.

17. Kozlov, S.A., Ignatov, A.B., 2012. Vlyianye yppodromnыkh yspыtanyi na vosproyzvodytelnuiu sposobnost kobыl orlovskoi rыsystoi porodы. Rezvostnoi klass y osobennosty vosproyzvodstva kobыl [Influence of racetrack tests on the reproductive ability of mares of the Orlov trotting breed]. Konevodstvo y konnyi sport. No. 4. pp. $10-14$.

18. Ignatov, A.V., 2009. Features of reproduction of horses of the Orlov trotting breed in the conditions of intensive selection for agility. Abstract of Ph.D dissertation. Moskow, https://www.dissercat.com/content/osobennosti-vosproizvodstva-loshadeiorlovskoi-rysistoi-porody-v-usloviyakh-intensivnoi-sele

19. 19. Suprun, I.A., 2020. Stan i perspektyvy zastosuvannia henetychnykh resursiv koniarstva v Ukraini. Tekhnolohiia vyrobnytstva i pererobky produktsii tvarynnytstva [Status and prospects of application of genetic resources of horse breeding in Ukraine]. Technology of production and processing of livestock products. No. 2. pp.66 - 75. DOI: 10.33245/2310-9289-2020-158-2$\underline{66-75}$

20. Suprun, I.O., 2020. Henetychni resursy rysystoho koniarstva v Ukraini. Visnyk Sumskoho Natsionalnoho ahrarnoho universytetu [Genetic resources of trotter horse in Ukraine]. Bulletin of Sumy National Agrarian University. Issue 3(42). pp. 67 - 76. DOI: $10.32845 /$ bsnau.Ivst.2020.3.12

21. Fomina, E.L., Miroshnikova, K.I., Valk, I.A., 1988. Vosproyzvodytelnaia funktsyia orlovskykh y russkykh kobыl v uslovyiakh Dubrovskoho konnoho zavoda. [Reproductive function of Orlov and Russian mares in the conditions of the Dubrovsky stud farm]. Intensification of breeding and horse breeding technology: Scientific works of VNIIK. pp. $190-201$.

22. Cotran E.G., Maccluer J.W., Weitkamp L.R., Pfenning D.W., 1984. Inbreeding and reproductive performance in standardbred horses. The Journal of Heredity. Vol. 75. No. 3. P. $220-224$.

23. Roche J.F., Kecnan L., Forde D., 1987. Some factors affecting fertility of the mare. Equine Practice. Vol. 9. No. 1. P. 8 12.

Suprun Iryna Alexandrovna, Candidate of Agricultural Sciences, Associate Professor

National University of Life and Environmental Sciences of Ukraine

The reproductive ability of stud trotting mares of different classes of speed

Recently, there has been observed a reduction in the amount of stud horses, decreasing in the level of reproduction and a tendency towards the irrationality of the stud structure in horse farms. Therefore, the aim of this study was to find out the current 
state of stud trotters in Ukraine simultaneously with the research of trotting mares reproductive capacity as a response to the intensity of racetrack tests. It is shown that stud trotters (Orlov, Russian, French trotting breed) has $26 \%$ of the total amount of stud horses in Ukraine at the beginning of 2020. In general, over the last fifteen years, the amount of the Orlov and Russian trotters has decreased by $60-81 \%$. It is detected an irrational structure of the herd in domestic horse breeding of Orlov breed as the share of the mare at the level of $36 \%$ is insufficient for prosperous reproduction of the herd. It is set that high effectiveness of racetrack tests of Orlov and Russian trotting mares renders negative influence on their reproduced ability. It is detected the reliable differences of level of nonimpregnation in Orlov and Russian trotting mares of the greatest class of speed and groups with the low results of racetrack test.

Key words: trotting breed of horses: Orlov, Russian, French, mare, speediness, racetrack tests, reproductive ability, intensity of the racetrack training.

Дата надходження до редакції: 22.11.2021 р. 